modelos de descrição, modelos de aplicação de testes, métodos de avaliação de funções, cargos e salários e integração do novo funcionário.

É interessante notar que a parte I não se destina a estabelecer a orientação clássica candidato $x$ vaga, funcionário $x$ função, mas sim a enriquecer a administração de pessoal com uma característica melhor ajustada à organização. A parte I é, com certeza, a introdução à parte II que é, sem dúvida alguma, a maior contribuição que o autor dá ao estudo da área de pessoal.

Nessa segunda parte são apresentados conceitos, políticas, estratégias, técnicas de desenvolvimento de recursos humanos, aspectos de introdução e dinamização de programas de desenvolvimento desses recursos, e treinamento e administração por objetivo.

Sabemos que a premissa básica de recursos humanos é a de assegurar a existência dos mesmos, disponiveis e adequados às suas operaçס̃es, presentes e futuras. Flávio de Toledo sugere algumas dessas premissas (seria nielhor dizer políticas), que são: a) melhor aproveitamento de condições para desenvolvimento constante e adequado de recursos disponiveis; b) assegurar que estes sejam preparados em nivel e com a antecedência necessária ; c) flexibilidade gerencial a fim de que seja possivel condição de exito permanente; d) criar e manter padrão de comportamento geral, de forma que não atue somente o setor especializado; e) tratamento por objetivos, mantendo sempre a avaliação de resultados.

Portanto, mentalização da cúpula da organização quanto à importância da área, ação associada às metas organizacionais, de curto e longo prazo, visando contribuir para um desenvolvimento organizacional que prepare a organização para enfrentar as conhecidas mudanças, que geram os conflitos de toda ordem.
O aspecto fundamental da obra é não só o fornecimento de amplo panorama da matéria, mas também, orientação e informação que possam resultar em aplicação prática. A forma de apresentação é essencialmente didática, útil a administradores e estudantes, dirigentes e executivos, na medida em que são apresentados tópicos testados no Brasil e no exterior.

A experiência de Flávio de Toledo é de inegável relevância, pois seu curriculum apresenta 25 anos de experiência na área de recursos humanos. Sua intenção neste livro é a de alertar a gestão de empresas para a importância da vinculação desta área à ação global da organização, contribuindo efetivamente para a possibilidade do conhecimento de meios que levam a uma razoável harmonia produtiva.

Para finalizar, um apelo à Editora Atlas, aliás, um apelo que vem se repetindo com relação a esta editora e algurnas outras: coloque 0 indice analítico no final do livro. Contando com o indice analítico, o leitor tem acessa mais rápido à informação de que necessita.

Luis Cesar G. de Araújo

\section{Strategie pour demain}

Por Mihajlo Mesarovic e Eduardo Pestel, Seuil, 1974.

Trata-se do segundo relatório apresentado pelo Clube de Roma. Seu objeto é tão vasto quanto 0 do seu antecessor, ${ }^{1}$ isto é, a sua amplitude engloba interesses que passam da economia para a politica, para a sociologia, para o campo da energética, demografia, etc. Todavia, os autores, através do reconhecimento implicito da validade das críticas formuladas ao crescimento exponencial e aos seus limites, preferem iniciar o livro convidando-nos a uma análise fria e imparcial.

Mais prudente, Mesarovic Universidade de Cleveland) e Pestel (Universidade de Hannover) apresentam um modelo bem menos abstrato. Esse modelo começa pela reintrodução da análise regional. Os dados relativos especificamente a alimentação, demografia, energia e crescimento são levantados e analisados em 10 modelos parciais (EUA, Japão, Europa Ocidental, Europa Oriental e URSS, Austrália e África do Sul, América Latina, Magreb e Oriente Médio, Africa Tropical, Sul da Ásia e China) autônomos, que 
posteriormente serão interrelacionados.

O próprio conceito de crescimento é formulado através da sua divisão entre crescimento celular, quantitativo ou exponencial e o orgânico. Neste último caso cada elemento é especifico e o seu processo de desenvolvimento è função de cada órgão. Este, por sua vez, será função do organismo como um todo.

Caso a humanidade opte pelo segundo tipo de crescimento, os prognósticos formulados em Limites do crescimento seriam infundados.

O aspecto energético, considerando a conjuntura por que passamos, ocupa lugar de honra. Das alternativas subexistentes, a única viável (e a mais improvável) ${ }^{2}$ é a da cooperação.

Mesarovic e Pestel propõem três estratégias que conduziriam à solução da atual crise do petróleo; a primeira, a curto prazo, seria baseada na cooperação com os paises produtores de petróleo; a segunda, a médio prazo, implicaria a gazeificaçăo e liquefação do carvão como complementação das atuais fontes de energia entre as quais o próprio carvão; a terceira, a longo prazo, repousaria na utilização da energia solar. As usinas produtoras deste tipo de energia seriam localizadas nos paises petroliferos, que, desta maneira, da sua posiçẫo de fornecedores.

Quanto à questão demográfica, os autores mantêm uma linha neutra. Principalmente após a experiência de Bucareste, ficou provado não ser esta a única variável a impedir a harmonia do desenvolvimento económico do Terceiro Mundo.

Abundante em informaçס̄es e dados, Strategie pour demain coloca os elementos em suas respectivas posiçōes, isto é, de profunda inter-relação. Falando em nome do ser humano, denuncia uma expansão desmesurada, baseada numa ex-

ploração depredatória da natureza e na solidificação de desigualdades existentes entre o norte e o sul do planeta.

Luis Roberto de Moraes Junqueira

1 Meadow, Denis H. Limites do crescimento. Perspectiva, 1973. (Coleção Debates, n. 90).

2 Parênteses e nota do autor.
From peasant to farmer: a revolutionary strategy for development

Por Raanan Weitz. New York, London, Columbia University Press, 1971. 292 p.

Os problemas das sociedades subdesenvolvidas, suas origens e hipotéticas soluções têm-se imposto como assunto central das preocupações acadêmicas e políticas nas últimas décadas. Recursos e esforços vultosos foram investidos no estudo dos fenômenos do subdesenvolvimento e na elaboração de planos e projetos concretos, destinados a modificar as condições socioeconômicas dos paises pobres.

Entretanto, uma avaliação criteriosa dos resultados desses esforços sugere que a compreensão do processo de desenvolvimento é ainda bastante vaga $e$, freqüentemente, permeada de mitos e falácias. Não se admira, portanto, que os tremendos esforços de induzir e dinamizar as economias dos países subdesenvolvidos tenham resultado em decepções e, não raramente, em fracassos.

Fato é que, ao ingressarmos no último quartel do século $X X$, aproximadamente $70 \%$ da população mundial que vive em mais de 100 países-membros 